\title{
Г.И. Марченко
}

\section{НАУЧНОЕ ОБОСНОВАНИЕ ГОСУДАРСТВЕННЫХ РЕШЕНИЙ В КНР: УЧЕБА \& КОНСУЛЬТИРОВАНИЕ}

\begin{abstract}
В статье, которая опирается на публикации Синьхуа и англоязычных исследователей, впервые в отечественной науке проанализирован уникальный опыт решения учебных и консультативных задач, рассматриваются технология, функиии, тематика, состав лекторов/экспертов и политические результаты учебных сессий членов Политбюро.

Ключевые слова: экспертное знание, принятие решения, имидж партии, учеба Политбюро КПК.
\end{abstract}

Приход к власти четвертого поколения руководителей во главе с Ху Цзиньтао (с конца 2002 года) ознаменовался изменением политического курса, ориентированного на повсеместное внедрение научных достижений, а также реализацию постоянно действующей обучающей программы высшего партийного руководства - Политбюро КПК. Профессор партийной школы ЦК КПК Чжоу Бинчэнг (Zhou Bingcheng), неоднократно принимавший участие в учебных сессиях Политбюро, отметил, что «рождение КПК, ее рост и развитие есть органичное соединение изучения марксизма с китайскими национальными условиями, которое непосредственно развивает управленческие способности» ${ }^{1}[1]$. Придя к руководству Китаем, Дэн Сяопин (Den Xiansheng, 1904-1997) в декабре 1978 г. поставил задачу переобучения партии в целом и разработки обучающей системы. Еще более тому способствовал и последующий поворот стратегии партии на экономическое развитие. После четвертого Пленума 13-го Центрального комитета КПК генеральный секретарь ЦК КПК Цзян Цзэминь (Jiang Zemin) придал обучению высших партийных кадров еще большую приоритетность. Но эти занятия проводились нерегулярно и концентрировались на юридических вопросах. Его преемник Ху Цзиньтао (Ни Jintao) на проведенном в конце 2002 г. 16-м съезде КПК ЦК КПК отчетливо сформулировал задачу обучения всех партийных руководителей и более четкой ее организации [2]. В сущности, этот же политический курс был продолжен Си Цзиньпином.

Проводимое Политбюро обучение способствует формированию стратегического взгляда на текущую ситуацию и на перспективу. В политической лексике руководителей страны большое место занимают такие понятия, как «стратегическая возможность», «стратегическое мышление», «стратегическое», «стратегическая задача», «стратегические шаги» и собственно «страте-

${ }^{1}$ Учредитель КПК Мао Цзэдун, любивший читать, сформулировал известный девиз «Чтение есть изучение и применение прочитанного, это есть обучение и еще более глубокое и необходимое постижение» [1]. 
гия». Это отражает акцент на полном и долгосрочном развитии с макрополитической точки зрения и глобальный образ мыслей. Такая стратегия с опорой на участие ведущих научных специалистов демонстрирует поучительный пример для местных органов власти, формирует общество, ориентированное на осуществление инноваций и проведение исследований.

Другой аспект такого рода практики связан с внесением историзма в государственное управление. Во всех таких занятиях подчеркивается историческая точка зрения - выявляется успешное и провальное в китайской и иностранной истории, что улучшает понимание тенденций развития и компетентность руководства государственными делами. То есть представление о прошлом углубляет политическую мудрость и усиливает власть.

Оценивая такого рода сессии, декан школы Партийной школы последипломного образования Луи Чун (Liu Chun) сказал, что они выражают политическую линию, ориентированную на мобилизацию коллективной мудрости в принятии решения в противовес здравому смыслу отдельных участников. Именно коллективное принятие решения есть гарантия правильности любых принятых решений [3]. Помимо того, обращение высшего руководства партии к представителям науки ярко свидетельствует о том, что китайская политика имеет фундаментальные научные основания и опирается на последние её достижения в социальной, экономической и др. сферах ${ }^{1}$.

Специфичность этих сессий определяется не только органической их увязкой с задачами управления партией государством и обществом, приданием любой обсуждаемой теме более широкого контекста - социального, международного и даже идеологического, ориентации на реализацию стратегической цели - развитие социализма с китайской спецификой. Данная форма отличается от традиционного политического консультирования, в котором большое значение имеют личность советника и разного рода личные интересы политика, с одной стороны, или всевозможные типичные для государственного управления совещаний. В то же время она близка особому типу научного консультирования, в котором ведущую роль играют представители не столько академической, но и прикладной науки, хорошо сознающие запросы политико-управленческой практики и выступающие в роли экспертов. Собственно, их преимущественно и привлекают к участию в китайских коллективных учебных сессиях.

\section{Технология}

В статье «Язвительные студенты, остроумные исследования», опубликованной 19 октября 2007 в газете «China Daily», характеризуется тщательно проработанная технология проведения данных занятий [3]. Они проводятся с периодичностью примерно в полтора месяца.

Начало подготовительного этапа работы над учебной сессией связано с выбором её темы и авторитетного научного учреждения, специализированного на её изучении, что обычно происходит в Главном управлении ЦК КПК (СРС). В число таких учреждений могут входить также и службы соот-

\footnotetext{
${ }^{1}$ Одна из восьми добродетелей, сформулированных Ху Цзиньтао, гласит: «Следуя за наукой, не будь невеждой».
} 
ветствующих министерств и центральных агентств, играющие главную роль в исследовании избранной проблематики. В некоторых случаях тема вытекает из указания определенного министерства, например Министерства иностранных дел.

Затем с руководителями отобранной организации проводятся переговоры о первоначальной формулировке предмета занятий, которая неоднократно уточняется, и делается подбор выступающих. Иногда, если тема глобальна, привлекаются эксперты из нескольких научных учреждений, которые также принимают участие в подготовке сессии [4].

Следующий шаг связан с работой экспертов над написанием проекта лекции, который пересылается для рассмотрения в Главное управление, оно, в свою очередь, формулирует свои предложения и отсылает их назад. После этого определяются руководящие принципы выступления, которые соединяют высокую информативность, чрезвычайную сжатость, раскрытие лишь самых важных проблем и доступность, лекция не должна быть излишне академической, учитывая, что аудиторию составляют члены Политбюро, министры и губернаторы провинций.

Разработка данного текста занимает немало времени - в течение 3 или шести месяцев пишутся несколько рабочих документов, основанных на обобщении мнений десятков экспертов и большого количества простых граждан. Окончательному занятию предшествуют, как правило, несколько раундов пробных лекций/обсуждений, по результатам которых в текст выступления вносятся различные поправки. В итоге распечатанный и раздаваемый лидерам текст отражает не столько индивидуальную позицию лектора, но обобщенный взгляд науки на тот или иной социальный или экономический вопрос.

Многие из выступавших в столь высокопоставленной аудитории в своих интервью единодушно подчеркнули различие между обычной лекцией и выступлением перед членами Политбюро. Такие выступления никогда не сводятся к популяризации общепринятых истин, но обсуждают использование теоретических положений для решения обсуждаемой проблемы и должны продвигать вперед развитие китайского общества.

Учебные сессии построены в формате, сопровождаемом кратким обсуждением. Каждая лекция читается двумя экспертами. Продолжительность сессии, как правило, 120 минут, в том числе каждый из выступающих говорит в течение 40 минут, затем - 30-минутное обсуждение, включая вопросы и ответы.

Один из выступавших перед Политбюро профессор исследований села Центрального китайского педагогического университета Сюй Юн (Xy Yong) наибольшую трудность в таких лекциях усмотрел не столько в самом монологе-лекции, сколько в двух- или трехминутных ответах на вопросы. Вопросы присутствующих всегда неожиданные, как правило, выходят за рамки подготовленного и распространяемого в аудитории текста и требуют мгновенной реакции. Данная аудитория отличается от прочих аудиторий большей интеллектуальностью и информированностью, глубиной понимания проблем [1]. Как считает декан Партийной школы последипломного образования (аспирантуры) Луи Чун (Liu Chun), присутствующие на сессии лидеры нередко расходятся в своих воззрениях на обсуждаемую проблему. Иногда точки зре- 
ния выступающих ученых и лидеров совпадают, но чаще возникают дискуссии, обмен мнениями [3].

В завершение председательствующий на сессии Ху Цзиньтао в течение десяти минут произносит итоговую речь. Иногда некоторые сессии превышали запланированное время, когда члены Политбюро проявили большой интерес к обсуждению вопросов. Например, сессия «Исторический обзор гонений китайского социализма» продлилась больше чем три часа, включая более часа на обсуждения после лекции.

Непосредственно сессия проводится в зале Чжуннаньхай (Zhongnanhai), в котором проводятся заседания руководства партии и Государственного совета (центрального правительства). Заседания всегда ведет сидящий напротив лекторов за столом Генеральный секретарь ЦК КПК, одновременно Председатель КНР.

Учебные сессии по сравнению с большинством заседаний Политбюро, отличающихся секретностью, предаются гласности, отчет о них публикуется информационным агентством Синьхуа. Точное время, тема и имена лекторов каждой прошедшей сессии публикуются обычно спустя сутки в китайском Интернете (Xinhuanet.com). При этом не обозначается полная программа и не описываются детали, но, главное, всегда публикуется завершающая речь руководителя страны. Имея в виду чуть ли мгновенную скорость публикации отчетов Xinhua, правомерно высказать предположение, что эти комментарии были подготовлены заранее и не отражают происходящие обсуждения на сессии. К этому же можно добавить, что освещаются эти сессии китайскими СМИ, ориентированными, прежде всего, на внутреннюю аудиторию [5].

Любопытно то, как одеты президент и присутствующие. Председатель КНР Ху Цзиньтао отказывается от обычного костюма с галстуком, выбирая застегнутую рубашку, иногда повседневную куртку. Другие участники следуют примеру президента, иные же в костюмах или военной форме. Приблизительно 20-25 человек, включая всех членов Постоянного комитета Политбюро, сидят за круглым столом в центре комнаты, в то время как президент Ху сидит у стены напротив группы. Вокруг стола находятся несколько рядов кресел, занятых остальными членами Политбюро и другими гостями. Телепоказ демонстрирует высокое внимание присутствующих на сессии и заметки на презентациях.

\section{Функции учебных сессий}

Первая функция этих сессий - информационная. Такого рода учебные сессии, без сомнения, расширяют возможности получения членами Политбюро научной информации и рекомендаций по специфическим политическим вопросам от ведущих экспертов Китая. Собственно, лекция не обязательно приводит к изменению политики, но формирует устойчивое знание, являющееся основанием для последующего принятия политических решений. Однако их конструктивный эффект кумулятивный и проявляется медленно, поэтому трудно предсказывать его конкретную величину. В целом функции этих занятий находятся во многом за пределами собственно информационных задач, безусловно, необходимых при принятии политических решений. Опрос ученых, выступавших в сессиях, показывает, что обсуждение практи- 
ческих проблем высшими руководителями и выступление экспертов являются скорее существенным консультативным моментом при принятии стратегических решений [4].

Коллективным сессиям изначально был свойствен символический и демонстрациионыци эффект. Обсуждая тему первой сессии - «изучение Конституции», новые лидеры четвертого поколения КПК как бы сообщали о том, что они как руководители настроены на утверждение верховенства закона и поддержку принципа «управления страной согласно закону».

Эти сессии используются в качестве примера для официальных лиц среднего и низшего уровня. По существу это сигнал о том, что все руководство должно посвящать больше времени и усилий улучшению своих знаний и навыков. Выступая на первой сессии, Ху Цзиньтао сказал: «Мы должны сделать обучение важной задачей для всей партии. Мы должны непрерывно усиливать и продвигать наши исследования, поднимать уровень научной и культурной изощренности» [6]. В то же время это есть знак того, что высшие руководители подчеркивают значимость профессионализма и специализированного знания; акцентируют роль коллективных обсуждений в принятии решений; придают процессу выработки тактики более «научный» и «консультативный» характер; стремятся извлечь полезные уроки из международного опыта для целей улучшения внутреннего управления.

Сессии часто используются для публичного обсуждения и продвижения новой политики и новых политических программ. Все новые идеи и программы текущего лидерства, строительство «новой социалистической сельской местности» или «гармоничного общества», «поддержка авангардного характера членов партии в новую эру» были превращены в темы соответствующих сессий. Эти сессии, включая завершающую речь лидера, определяют необходимые действия и убеждения партийных и правительственных руководителей, превращаются в заголовки новостных сообщений и являются свидетельством того, что эти программы получат дальнейшее развитие.

Иногда сессия является элементом идейно-пропагандистской поддержки празднования исторических событий. В частности, 80-летней годовщины основания Народной Освободительной армии (PLA) (сессия 1 августа 2007) или шестидесятилетней годовщины конца Второй мировой войны (сессия 26 августа 2005). Кроме привлечения общественного внимания к такому событию, это также показ отношения китайских лидеров к истории: социалистический Китай не забывает прошлого и стремится извлечь из истории полезные уроки для сегодняшнего дня.

Другая функция связана с формированием согласия (консенсуса) в высшем руководстве, которое является необходимым условием для принятия и исполнения решений. Совместное изучение проблемы облегчает достижение взаимопонимания и договоренностей о плане действий.

Важная функция, выполняемая сессиями, состоит в политическом рекрутировании. Иногда высшие должностные лица Китая выбирают себе помощников и консультантов непосредственно из академических кругов. Выступающие на сессиях ученые, которые производят на высшие должностные лица впечатление знаниями, аналитическими навыками и стратегическим видением, быстро получают правительственные должности или места в кон- 
сультативных командах. Например, исследовательница Академии социальных наук Цзян Ксяошан (Jiang Xiaojuan), прочитавшая лекцию на сессии (2003) после выступления была назначена на должность заместителя директора Исследовательского управления Государственного совета. Бывший президент университета Тонгжи (Tongji) Ван Ганг (Wan Gang) и сейчас успешно возглавляет Министерство науки и техники. Конечно, в кадровой политике любое решение о продвижении не может основываться на одной лекции, прочитанной пусть и в столь высокой аудитории, но учебные сессии позволяют китайским лидерам взаимодействовать с талантливыми учеными, формировать мнение об их потенциале, а в иных случаях их способности использовать и в государственном управлении.

Что же касается собственно академических ученых, то у них появляется редкая возможность непосредственного контакта с политиками высшего уровня. Даже участие в долговременной подготовке сессии ведет к интенсивному взаимодействию с ключевыми консультантами Политбюро, многими высокопоставленными должностными лицами. В результате часто возникают приглашения на формальные обсуждения высокого уровня, возникает силы, содействующие дальнейшему продвижению.

Конечно, высшие руководители для этого всегда располагают формальными и неофициальными каналами и могут в любое время пригласить любого эксперта на обсуждение или организовать те или иные семинары с приглашением многих экспертов. Но коллективные сессии отвечают многим целям и отличаются от обычной консультации лидеров со специалистами по политике или стратегическим проблемам тем, что каждая сессия - тщательно подготовленное событие, процесс подготовки к ней отличается сложностью с включением в него различных агентств и команд исследователей.

Немалое значение имеет и имиджевая функция учебных сессий, позволяющая действующему политику Китая формировать имидж, отличающий его от прочих лидеров. После того как команда текущих лидеров вступила в должность, она должна ясно сформулировать новое видение перспектив развития страны, новую политику и её методы, изменившийся стиль лидерства. Последние лидеры Китая Ху Цзиньтао и Си Цзиньпин проводят в жизнь принцип научного, демократического и основанного на законе управления, а коллективные сессии служат формированию позитивного их имиджа как людей, которые утверждают защищаемые идеи на практике, внедряют инновации в их стиль лидерства.

\section{Тематика сессий}

Выбор темы коллективного изучения всегда осуществляется двумя способами. Во-первых, ее может выбрать кто-то из высокопоставленных руководителей, во-вторых, она выбирается ЦК КПК и какой-либо иной группой, но всегда за такой темой стоит ощущение злободневности проблемы.

Тематика исследовательских занятий, направляемых партией, весьма широка и охватывает экономику, политику, культуру, общество, международные проблемы, вооруженные силы и партийное строительство. Обобщенно она связана с различными предметными сферами, которые всегда тесно увя- 
заны с конкретными вопросами политики, точнее, проблемами, стоящими на повестке дня Китая.

Одни из них совершенно конкретны - сельскохозяйственное развитие, занятость, образование и здравоохранение, защита прав на интеллектуальную собственность и безопасность пищевых продуктов. В центре других - более абстрактные теоретические или идеологические проблемы, такие как развитие марксистских теорий за рубежом и внутри страны, пути и методы строительства «социалистического гармоничного общества» [5].

Авторы книги «Новые акторы китайской внешней политики», проанализировавшие тематику 66 сессий, проведенных по июль 2010 года, пришли к выводу, что большинство из них сосредоточились на вопросах внутренней политики или идеологических проблемах. Примерно треть лекций затронула конкретные аспекты международных событий в их воздействии на Китай. Как было отмечено исследователями, в тематике сессий важные для партийного руководства вопросы отсутствовали: в частности, движения протеста, коррупция, Тайвань, США-Китайские отношения, Азиатский регионализм [7. C. 34].

Несколько сессий посвящены историческим темам, например истории этнических отношений в Китае и развития основных сил в мире с 15-го столетия, семь посвящены истории сессий затрагивали историю Китая (5 сессий), две - всемирную историю. Из пяти тем, касающихся истории Китая, 4 касаются истории КПК и его революционной борьбы.

Ключевая тема сессий - «внешний мир», она обсуждалась около 30 раз. Это свидетельствует о придании руководством КПК большого значения практике и опыту других стран, об увязке развития Китая с глобальным пространством, а такой подход показывает широту воззрений и открытость к иным идеям. Международные темы касались значимости международной торговли, природы глобальной политической экономики, глобальных военных преобразований, а также истории подъема и падения империй в современную эру. Сессии, на которых изучались внутренние и международные темы, включали вопросы китайской энергетической безопасности, развития китайской культурной индустрии, прав на интеллектуальную собственность, взаимозависимости экономического развития и сильной национальной обороны, «антифашистской войны» против Японии [5].

Иногда тема обретает специфику, когда обсуждается существующая в Китае проблема, но рассматривается она сквозь призму международного опыта. Например, «Системы и меры обеспечения производственной безопасности в зарубежных странах и системы безопасности в Китае». Или «Модели урбанизации зарубежных стран и специфика урбанизации в Китае».

Ключевая тема исследовательских сессий связана с «верховенством закона»: из 44 сессий, проведенных с 2002 по 2007 г., семь было посвящено данной теме. Весьма интересна эволюция данной темы. Так, преподаватель Джао Зиян (Zhuо Zeyuan) провел две лекции в 2006 и 2011 гг., тематика которых была, казалось бы, предельно близкой. Тема первой лекции была обозначена как «Управление, которое опирается на закон и имеет научный и демократический характер». Вторая же лекция была сформулирована как «Управление, базирующееся на верховенстве закона; оно углубляет понимание обществен- 
ностью социалистического строительства страны и предоставляет закону полную свободу в социально-экономическом развитии». Совершенно очевидно, что изменения в названиях отразили более отчетливый приоритет принципа «верховенства закона» в Китае. В первой лекции подчеркивалось основанное на законе управление партии, во второй - гарантии правления правительством согласно закону [8].

Эксперты партийного мозгового центра обратили внимание на то, что принцип «верховенства закона» коренным образом изменился. Ранее он сводился во многом к законности и правопорядку, сегодня его толкование расширилось - это означает удовлетворение всесторонних потребностей, а также всестороннее развитие институциональных оснований и правовой защиты [8]. Верховенство закона основано на эффективной защите гражданских свобод и прав человека, а эффективное ограничение государственной власти зависит от соответствующей политической, экономической и культурной структуры [9].

Руководящая роль партии также нашла свое отражение в тематике соответствующих сессий: с 2003 по 2011 год Политбюро ЦК КПК провело десять коллективных сессий, посвященных проблеме партийного строительства и обсуждению вопроса об авангардной роли партии. Особое значение было уделено улучшению управленческих и лидерских способностей, нацеленных на решение проблем, с которыми партия столкнулась после основания социалистического Китая. В связи с 83-летием рождения партии 30 июня 2004 г. было организовано занятие по улучшению навыков партийного лидерства ${ }^{1}$.

28 июня 2011 года профессор Центральной партийный школы Ку Кингшен (Qu Qingshan) и профессор университета Ренмин (Renmin) Китая Янг Фенг (Yang Feng) были приглашены на сессию «Поддержка и развитие продвинутого изучения природы Китайской коммунистической партии» [10]. Открывая занятие, Ху Цзиньтао отметил необходимость постоянного обращения к истории партии, подведения итогов нового опыта, важной задачей является внедрение инноваций в её деятельность и устройство.

Большое внимание на сессиях уделяется проблемам экономического развития. Например, в ответ на субстандартный ипотечный кризис в США была проведена соответствующая сессия. На съезде партии (ноябрь 2007) были отмечены и значительные успехи, но высказано и требование ускорения экономического развития, улучшения социалистической системы рынка. В апреле следующего года была проведена учебная сессия Политбюро, в названии темы которой сделан акцент на исследовательском аспекте - «Ускорение исследований $(!-$ Г.М.) экономического развития Китая». Она была проведена в связи с тридцатилетием реформ и открытостью Китая миру, что вместе с курсом на построение социализма с китайской спецификой и опорой на науку привело к масштабным успехам. С этого времени развитие страны с опорой на науку вошло в программу коллективного обучения региональных и местных партийных организаций, обрело стратегический смысл [11].

Темами многих сессий стали социальные проблемы китайского общества - занятость, экология, сельское население и пр.

\footnotetext{
${ }^{1}$ КПК была основана 1 июля 1921 г.
} 
Показательна двадцать третья сессия Политбюро (конец сентября 2010), прошедшая на тему «Правильное управление противоречиями между людьми новой эры». Смысл и истоки противоречий связывались с конфликтами, которые порождаются всевозможными разрушительными социальными причинами. В ходе сессии Ху Цзиньтао сформулировал четыре требования. Выяснить источник конфликтов и сократить их количество. Сосредоточиться на защите прав граждан, особенно на работе в массах. Увеличить число инноваций в социальное управление. Также подчеркивалось, что партийные комитеты и правительства всех уровней должны воспринимать работу с противоречиями среди людей как основную работу, включенную в повестку дня (agenda).

Кроме этого, была проведена сессия по истории отношений между меньшинствами в Китае - среди политических приоритетов КПК находится задача гармоничного и преуспевающего развития меньшинств. Но наиболее сложной для страны является проблема занятости.

На февральской сессии 2012 года Ху Цзиньтао более чем критически оценил ситуацию с трудоустройством в стране как «суровую», она может сохраниться таковой и в предстоящие годы. Наиболее проблемными категориями в этом плане он назвал выпускников вузов, мигрантов с сельской пропиской, демобилизованных военнослужащих, женщин, инвалидов и представителей нацменьшинств. Одновременно он сообщил о том, что будет оказана практическая поддержка различным организациям, занимающимся трудоустройством, усилена финансовая и социальная помощь безработным [12].

Политбюро также организовало лекцию по развитию философии и общественных наук в Китае. Сам выбор темы всегда есть мощный политический сигнал, говорящий о необходимости развития не только экономики, но и так называемой мягкой силы. Практическим результатом стала организация сотни академических проектов в целях развития общественных наук.

В своем выступлении на сессии (2007) Ху Цзиньтао объявил о полном разрыве с традиционными атеистическими постулатами и о новом политическом курсе в отношении религии. Он заявил, что нравственные силы религии могут и должны быть использованы на благо партии и общества. «Мы должны стремиться к тесному объединению религиозных деятелей и верующих вокруг партии и правительства». Финансируемые правительством исследования выявили большое количество верующих - четверть населения (300 млн чел.), а традиционными религиями Китая считаются буддизм, даосизм и ислам. Христиане насчитывают 40 млн чел., среди них большинство составляют протестанты, католиков же - 12 млн [13].

Ряд сессий сконцентрировался на проблемах культуры. В январе 2007 года лекция перед членами Политбюро была посвящена развитию Интернета в Китае. Ху Цзиньтао убеждал присутствующих лидеров в необходимости повышения у них интернет-грамотности в целях «улучшения искусства лидерства». Кроме того, три человека в центральной провинции Хэнань (Yunnan), представляющие местную ассоциацию пользователей сети, стали законодателями и политическими консультантами. В этом факте можно увидеть беспрецедентный выход «пользователей сети из виртуального пространства на политическую арену реального мира» и стремление высшего руководства 
к развитию «интернет-демократии». В январе 2009 г. число пользователей Интернета (Интернет-население) составило 300 млн китайцев, или $23.8 \%$ населения и стало самым большим в мире [14]. По данным Международного союза электросвязи, число пользователей выросло к 2016 году до 710 млн человек и опережает все страны мира [15]. Правительство Китая, точнее, Министерство промышленности и информационных технологий осуществляет регистрацию сайтов и контролирует их содержание.

23 июля 2010 года на сессии обсуждались реформа так называемой индустрии культуры и улучшение мягкой силы на международной арене. Было провозглашено, что в этих целях партия должна активно работать в защиту национальных традиций в культуре и против «трех пошлостей»: вульгарности (точнее откровенных телевизионных реалити-шоу), пошлости (порнографии и соответствующей музыки в Интернете) и китча (подражания дешевым образцам) стиля. В течение пяти лет должно также увеличиться финансирование на творческие отрасли (культуру) до 5\%, сегодня оно составляет только $2,75 \%$ ВВП [16].

В очередной сессии, 23 августа 2011 года, обсуждалась земельная проблема, связанная с нехваткой земли для потребностей экономического развития страны [14]. После выступлений эксперта Центра развития экономики сельского хозяйства Госсовета Луи Шоуиинга (Liu Shouying) и професcора департамента городских и экологических наук Лин Джиэнфу (Lin Jianfu) Xу Цзиньтао подчеркнул огромную значимость земли для выживания человечества и развития его материальных оснований, а также недостаточность земельных ресурсов в Китае [17].

Председатель КНР отметил, что быстро развивающееся землеустройство Китая столкнулось со многими новыми ситуациями и новыми проблемами. Необходимо оценить степень удовлетворения текущих потребностей в земле, но «защитить выживание будущих поколений». Должен рационально использоваться каждый дюйм земли, необходимо опираться на научные принципы, защищающие национальную продовольственную безопасность и соединяющие со стратегическими целями.

В сессии, посвященной развитию экологии, было высказано требование строительства ресурсосберегающего и благоприятного для окружающей среды общества, включающего каждое домохозяйство. Относительно недавно принят запрет на бесплатные пластмассовые хозяйственные сумки. Их предоставление наказывается штрафом в размере 10 тысяч юаней (около 1500 долларов), что привело к прекращению их продаж в основных предприятиях розничной торговли [18] $]^{1}$. Один из практических результатов - около $60 \%$ используемых пластиковых сумок, приобретаемых в супермаркетах, позволило снизить производство на половину миллиона тонн пластика и сократить выбросы углекислого газа на 9,6 млн тонн. Согласно отчету Национальной комиссии развития и реформ (NDRC), этот запрет породил экономию от 2,4 до 3 млн тонн нефти в год [18].

\footnotetext{
${ }^{1}$ Аналогичный запрет в Ирландии, Индии, ряде городов США и других странах резко сократил их употребление.
} 


\section{Лекторы или эксперты?}

Выбранных для выступлений лиц правомерно считать главными экспертами в их областях знаний. Так как большинство сессий сосредоточивается на конкретных вопросах политики, то анализ аффиляции лекторов отвечает на вопрос о научно-исследовательских институтах, имеющих наибольшее влияние на принятие политических решений в Китае.

Проведенный анализ лекций за десять лет, с 2002 года, показывает институциональное представительство выступавших лиц (142 чел.). Большая часть из них (24 чел.) из Китайской Академии социальных наук (Chinese Academy of Social Sciences), 11 - от Исследовательского центра развития Государственного совета (Development Research Center under the State Council); по восемь - из Института экономических исследований национального развития, Комиссии по реформе и Академии военных наук. Семь и шесть человек - из Партийной школы и Исследовательского центра истории партии, которые непосредственно подчинены ЦК КПК.

Хотя лекторы для сессий выбирались по всей стране, большая их часть (60\%) работает в девяти расположенных в Пекине исследовательских и академических учреждениях, что выражает влияние близости к центральным органам власти на их выбор. Более чем половина лекторов (87 чел.) представляют правительственные научно-исследовательские институты, включая научно-исследовательские институты армии и партии. Только 29 из них работает в университетах. Видная роль правительственных исследователей в этих сессиях показывает принципиальную роль информационноаналитических структур правительства в процессе принятия политических решений. В последние годы правительство Китая стремится придать политическому процессу большую открытость, вовлекая в него и независимых академических ученых из университетов [4].

Проведенный анализ состава лекторов показал, что за весь период с конца 2002 по август 2011 года выступило 145 ученых, но редко кто принял участие в сессиях - дважды. Средний их возраст составляет около 50 лет, иногда и моложе, самому молодому из лекторов на момент исследования исполнилось 38 , старшемy - 73. Они имеют хорошее образование и докторские степени иностранных университетов, а продолжительное проживание некоторых из них в другой стране привносит полезную внешнюю перспективу в идущее на сессии обсуждение. Большинство из них занимает относительно низкие формальные позиции в научной иерархии. Однако при всей специфичности эти сессии носят действительно академический характер, так, на сессии по экономике приглашаются ученыеэкономисты, но не предприниматели [4].

\section{Продолжение при Си Цзиньпине}

Преемник Ху Цзинтао Си Цзиньпин, ставший руководителем партии 15 ноября 2012 и председателем КНР 14 марта 2013, подтвердил курс на обучение высших политиков Китая в форме коллективных сессий. В своем выступлении в марте 2013 года он отметил, что «это успешный опыт, способствующий развитию КПК и китайского народа». Он подчеркнул, что эта форма постоянно совершенствуется, и добавил, что «мы должны применить то, что 
мы учимся в практике, одновременно улучшая себя». Его активность в этом направлении немного повысилась: за аналогичный трехлетний период было проведено 30, у Ху Цзинтао - 27 сессий, была изменена и технология проведения одной из них (30 сентября 2013) - по вопросам инновационной стратегии. Было изменено место проведения - не в привычном для таких занятий зале Чжуннаньхай, но в Научном парке Чжунгуаньцунь, его называют Силиконовой долиной Китая. В сессии соединились полевое обследование, характеристика его методов и результатов, а также традиционная дискуссия.

Основными выступающими также были ведущие должностные лица национальных ведомств, ученые из научно-исследовательских институтов, а также руководители приграничных провинций. Например, лекторами по теме «Борьба с коррупцией в китайской истории» были Бу Синкван (Bu Xianqun), научный сотрудник Института истории Китайской академии социальных наук (CASS), и Фанг Нин (Fang Ning), исследователь из Института политологии этой же Академии.

Как и ранее, дважды обращались к изучению вопросов марксистской философии, а также основным принципам и методологии марксистской политической экономии. Пять сессий было посвящено вопросам истории, в том числе борьбе с коррупцией, теории и практике китайского социализма, национального управления, войне против японской агрессии и китайскому патриотизму в истории Китая.

Темами докладов и выступлений других сессий стали перспективы партийного строительства, углубление реформ, экономическое строительство, развитие культуры, общества, национальной обороны и укрепления армии. И, наконец, на тридцатой сессии (29 января 2016) состоялось обсуждение стратегических приоритетов экономического и социального развития Китая в 13-й пятилетке [19].

\section{Политические результаты сессий}

После лекции Ксу Юонг центральное правительство сформулировало несколько ориентированных на село стратегий, которые «взяли на вооружение рекомендации, предложенные в лекции». Эта лекция по демократии в сельском обществе и состоявшееся после нее обсуждение стали исходным пунктом кампании, которая началась в 2002 г. и была нацелена на преодоление увеличивающегося разрыва между развитием города и села.

В 2009 г. исследовательница Института Европы Китайской Академии социальных наук Джоу Гонконг (Zhou Hong) в выступлении на Политбюро оценила систему социальной защиты Китая как лучшую в мире и внесла предложения по её развитию. Позднее она отметила в интервью, что данная сессия Политбюро внесла заметное ускорение в реформу социального обеспечения в Китае [3].

В августе 2006 г. Занг Ли (Zhang Li), глава Национального Центра исследования развития образования, прочел лекцию по реформе образования Китая. В 2007 г. была объявлена новая политика, предоставляющая новые возможности свободного поступления в университет.

За три дня до визита в Россию 27 июня 2005 г. была проведена 23-я сессия об энергетических ресурсах как в стране, так и в мире, завершая её, Ху 
Цзиньтао сделал хорошо подготовленный комментарий о необходимости сотрудничества в этой сфере. С той поры по данной проблеме прошло еще три сессии, тематика которых была связана или с потреблением Китаем энергии или с выбросами парниковых газов. Их участник вицепредседатель Национального энергетического консультативного комитета Жоу (Zhou) таким образом оценил соответствующий результат: «Первые из них сформировали у высших руководителей систематическое введение в энергетическую ситуацию Китая (изобилие ресурса, потребление, сохранение и безопасность). Ретроспективно можно сказать, что эти обсуждения заложили прочный фундамент для принципов энергетической политики, которые затем последовали» [4]. Начиная с 2006 г. руководство страны стало придавать большее значение энергосбережению, сокращению загрязнения. Впервые именно в этом году в пятилетний социальноэкономический план развития страны была внесена как обязательная цель улучшения эффективности использования энергии на $20 \%$.

В результате сессии о развитии сельской демократии несколько областей, включая восточный экономический центр Цзянсу и Чжэцзян, выстроили соответствующие программы, гарантирующие соблюдение демократических принципов и правильность принимаемых правительством решений.

Распространение модели учебных исследовательских сессий за пределы высокопоставленных должностных лиц привело к тому, что больше 540000 региональных руководителей глубже изучили теорию партии, а больше 5400 человек обучились более эффективным методам развития сельского хозяйства.

По мнению ряда аналитиков, принятая на вооружение система обучения, - это постоянно действующая особенность коллективного управления, одновременно выражающая принципиальную и последовательную позицию Китая в решении специфических вопросов. Она обеспечивает лидерству консенсус и эффективность [3]. Для внешнего мира проводимые Политбюро учебные занятия чрезвычайно важны, так как указывают на проблемы, на которых фокусируется внимание высшего руководства страны и всего общества.

Характер обсуждаемых тем в сочетании с установками лидеров не сводится лишь к советам политикам. Это есть сила, увеличивающая потенциал всех уровней политического управления, а её механизм проявляет конституционный принцип, обеспечивающий соединение «коллективного руководства и индивидуальной ответственности». В свою очередь, весь процесс подготовки и проведения сессий Политбюро есть часть реальной политической жизни и одновременно решение проблемы координации различных звеньев и уровней руководства. Как заметила авторитетная американская газета «Нью-Йорк Таймс», ушла в историю действующая в течение многих лет неинституциализированная и окутанная секретностью система неформальных встреч и конференций высшего руководства в курортном районе Бэйдайхэ (Beidaihe) [20] $]^{1}$.

\footnotetext{
${ }^{1}$ Такого рода встречи были отменены по указанию Ху Цзиньтао в 2004 году в основном по двум причинам. Во-первых, они противоречат скромному стилю руководства Ху Цзиньтао и Вэнь Цзябао. Во-вторых, это есть выражение стремления работать через официальные партийные и государственные механизмы, а не через неформальные встречи [20].
} 
Что же касается практики коллективного обучения Политбюро ЦК КПК, то она обрела стратегический характер и говорит о том, что центральное руководство партии взяло на себя инициативу в интенсификации обучения повсеместно в партийных рядах.

На 17-й и 18-й съезды партии было приглашено большое количество низовых представителей партии и экспертов в качестве полноправных наблюдателей за их ходом. Замдиректора Института политических исследований Китайской Академии социальных наук Фэнг Нинг (Fang Ning) отметил, что деятельность Центрального комитета и Политбюро, а также местных комитетов КПК разных уровней отчетливо характеризуется внутренней открытостью и расширением внутрипартийной демократии.

Аналитики обращают внимание на то, что именно институционализация сил и полномочий лидеров обеспечивает коллективное принятие решений и повышает эффективность их реализации. Собственно учебные сессии Политбюро укрепляют также традицию самокритики и самосовершенствования непрерывно развивающейся партии [11].

Эти сессии не типичное для управленческой практики собрание, а это платформа ведущих руководителей страны, стремящихся лучше узнать проблемы партии и общества. В то же время это не дебаты или мозговой штурм, отчетливо нацеленные на подготовку решений, так как у членов Политбюро расширяется понимание важных проблем, находящихся на стадии становления, тем более что такие именно проблемы часто сталкиваются с незрелостью административного мышления и бюрократическими препонами. Это важно, поскольку многие китайские высшие руководители получили техническое образование, и для них более чем необходимо расширение знаний в мировой экономике, всемирной и отечественной истории.

Обучающие сессии служат также и усилению влияния первого руководителя страны, а также генерального секретаря и лидера правящей коммунистической партии. Сессии создают для него платформу для утверждения представлений по разнообразным темам, определяют установки, которым другие члены Политбюро должны следовать.

Гласность данных сессий помогает также улучшить общественный имидж китайского лидерства. В то время как многие китайцы выдвигают требование повышения прозрачности (транспарентности) правительства, то сессии есть ответ на этот запрос, формирующий имидж открытого и ответственного лидерства. Даже неформальность одежды присутствующих на сессиях работает на образ лидеров, неуклонно стремящихся понять и проанализировать стоящие перед китайским обществом проблемы. Хотя сессии - это всего лишь часть процесса принятия политических решений Политбюро, но они приоткрывают его внутренний механизм, информационный доступ к которому не обеспечивали предыдущие лидеры. Они отходят от таинственности, присущей деятельности Политбюро предыдущих созывов, и это мастерски было использовано Ху Цзиньтао для подчеркивания отличий от руководства Цзян Цзэмина (Jiang Zemin). Кроме того, освещение сессий в СМИ расширяет возможности для первого лидера выразить свое понимание проблем партии и предложения менее формальным способом. 
Сессии также продвигают имидж Политбюро, которое серьезно размышляет обо всех проблемах, волнующих китайский народ. Темы сессий по аграрной политике, политическим правам для меньшинств, занятости и помощи безработным, атипичной пневмонии и продовольственной безопасности по существу есть послание (месседж) лидеров, нацеленное на определенные слои, говорящее об отзывчивости к их потребностям и призванное предотвратить возникновение возможных движений протеста.

Практически все обучающие сессии при оттенках высказываемых мнений подтверждают идеологические основы партии и лидеров. Практически на каждой сессии звучат заверения о верности марксизму, теориям Мао Цзэдуна, Дэн Сяопина, «трех представительствах». Поскольку партия проводит в жизнь идею строительства в XXI веке социализма с китайской спецификой, то сессии используются для утверждения этой идеи в целях подтверждения законности идеологических основ партии и их незыблемости.

В завершение статьи приведу слова Элис Лайман Миллер (Alice Lyman Miller), китайского ученого Стэнфордского университета и редактора журнала «Монитор китайского лидерства» (China Leadership Monitor ${ }^{1}$ ), которая удивляется «тому, что все Политбюро коммунистической партии Китая сидит без дела и слушает академиков в течение многих часов» [22]. Большей сдержанностью отличаются суждения известного китайского социолога Хуань (Huang), увязавшего политическую систему Китая с разработками мозговых центров. «Для исследователей исследование бессмысленно, если оно не будет учтено лицами, принимающими решение. Столь же скверно, если лишь один из высших руководителей будет ознакомлен с результатами исследования». И завершил свою мысль не вызывающим сомнений признанием: «Я не думаю, что существует какая-либо другая страна, которая создала, подобно нашей, систему групповых учебных сессий для всех высших руководителей» [4].

Если же взглянуть на данный политико-управленческий опыт отвлеченным взором политолога, то надо признать, что его огромная полезность порождена тем, что здесь на присущий любому высокому руководителю опыт наслаивается взгляд науки на обсуждаемую проблему. Тем более что в ходе любой из вышеупомянутых сессий характеризуется и опыт её решения в других странах, и сложившиеся в истории Китая традиции, помноженные на высший идеал политики КПК - строительство социализма с китайской спецификой.

О внедрении подобной практики в государственное управление нашей страной приходится только мечтать!

\section{Лuтература}

1. A crucial measure for CPC to enhance governing capability. October 11, 2007 // The 18 th National Congress of the Communist Party of China: Press Center / People's Daily Online : site. [Электронный ресурс]. URL: http://english.cpcnews.cn/92275/6281233.html (дата обращения: 11.10. 2014)

\footnotetext{
1 Этот журнал выпускается при поддержке Института Гувера войны, революции и мира, являющегося частью Стэнфордского университета. По существу это один из влиятельных «мозговых танков» или «фабрик мысли» (think tanks), с ежегодным бюджетом 19 млн долл., работающий на основе неправительственных заказов, в его штате около 70 постоянных экспертов по экономике, праву, истории, образованию и социологии [21].
} 
2. Yiyi $\mathrm{Lu}$. The collective study sessions of the Politburo: a multipurpose tool of China's central leadership. China Policy Institute. University of Nottingham. October 2007. United Kingdom. Briefing Series - Issue 27. [Электронный ресурc]. URL: http://www.nottingham.ac.uk/cpi/documents/ briefings/briefing-27-collective-study-sessions-of-the-politburo.pdf (дата обращения: 07.11.2014)

3. Sharp students, smart studies // China.org.cn : site. [Электронный pecypc]. URL: http://www.china.org.cn/english/congress/228788.htm (дата обращения: 19.05.2013).

4. Wu Wencong, Jiang Xueqing, Li Jing. Where 'top student' has a new meaning. 16 Yan 2012 // China Daily.com.cn USA : site. [Электронный pecypc]. - URL: http://usa.chinadaily. com.cn/china/2011-11/29/content_14177847.htm (дата обращения: 20.11.2015)

5. Saunders Phillip $C$. The Chinese Politburo Hits the Books // China Brief. Volume 6. Issue 15. May 9, 2007 / The Jamestown Foundation : site. [Электронный pecypc ]. URL: http://www. jamestown.org/articles-by-author/?no_cache $=1 \&$ tx_cablanttnewsstaffrelation_pi1\%5Bauthor\%5D=367 (дата обращения: 9.05.2012)

6. Politburo 1st Studying Hu Jintao: to improve the governing and rejuvenating the ability to enhance learning // Xinhua News Agency / Xinhuanet : site. [Электронный pecypc]. URL: http://www.news.xinhuanet.com/english/2002-11/15/content_630977.htm (дата обращения: 22.02.2014)

7. Jakobson L., Knox D. New Foreign Policy Actors in China. SIPRI Policy. Paper No. 26, 2010. [Электронный ресурc]. URL: http://books.sipri.org/files/PP/SIPRIPP26.pdf (дата обращения: 24.12.2015).

8. Chinese top leaders' collective learning over past 10 years. August 02, 2011 // People's Daily Online: site. [Электронный pecypc]. URL: http://english.peopledaily.com.cn/90785/7458169.html (дата обращения: 07.04.2016).

9. Social Signs Point China to The Rule of Law. A Century Weekly editorial, 13.06.2011 // Caixin Online: site. [Электронный pecypc]. URL: http://english.caixin.com/2011-06-13/100268658. html (дата обращения: 13.07.2011). Dong Ruifeng 董瑞丰, “集体学习的政治智慧” (The political wisdom of collective study), 辽望 (Outlook), 4 July 2011, P. 38-39.

10.Hu calls on nation to continue reform, opening up // China.org.cn: site. [Электронный pecypc]. URL: http://www.china.org.cn/government/news/2008-12/28/content_17021754.htm (дата обращения: 19.01.2015).

11. 胡锦涛 : 实施更加积极的就业政策 努力实现社会就业更加充分 Ху Цзиньтао: осуществлять более активную политику в области занятости и социальных усилий для достижения более полной занятости // Cpcnews.cn: site. [Электронный pecypc]. URL: http:// cpc.people.com.cn/GB/64093/64094/17178056.html (дата обращения: 13.04.2015)

12. Cody E. Chinese government rethinks religion. Communist party now believes faith can restore social harmony // Washington Post. January 26, 2008.

13.Netizens change China's political landscape // China.org.cn: site. [Электронный ресурс]. URL: http://www.china.org.cn/china/opinion/2009-02/28/content_17349597.htm (дата обращения: 28. 02. 2012)

14.Пользователи Интернета в мире // Интернет в России и в мире: сайт. [Электронный реcypc]. URL: www.bizhit.ru/index/polzovateli_interneta_v_mire/0-404 (дата обращения: 22.07.2016).

15. Bandurski D. The bandwagon of soft power // China Media Project: site. [Электронный pecypc]. URL: http://cmp.hku.hk/2011/10/24/16622 (дата обращения: 24.10.2015).

16.Hu Jintao, CPC Central Committee Political Bureau of the thirty-first collective study stresses the importance value and rational use of every inch of land // Free Paper: Free News, China News, U.S. News, World News, Provides newspaper for all industries. August 24, 2011. [Электронный реcypc]. URL: http://www.f-paper.com/?i815087-Hu-Jintao-CPC-Central-Committee-Political-Bureauof-the-thirty-first-collective-study-stresses-the-importance-value-and-rational-use-of-every-inch-ofland (дата обращения: 16.01.2014).

17.Guo Qiang. Plastic-bag ban paying off // Global Times: site. [Электронный pecypc]. URL: http://www.globaltimes.cn/content/461593.shtml (дата обращения: 27.08. 2009).

18.Top Chinese leaders' class: 30 collective studies of the 18-th CPC Politburo // People's Daily Online : site. [Электронный pecypc]. URL: http://en.people.cn/n3/2016/0204/c98649-9014098.html (дата обращения: 4.02.2016).

19.Kahn J. Chinese Leader Cancels Communists' Seaside Retreat // The New York Times. August 04, 2003. [Электронный ресурс]. URL: http://www.nytimes.com/2003/08/04/world/chineseleader-cancels-communists-seaside-retreat.html (дата обращения: 19.10.2015). 
20.Водин Р. Гуверовский институт - «мозговой танк» // Альманах «Восток»: сайт. [Электронный ресурc]. URL: www.sitiation.ru/j_art_377.htm (дата обращения: 18.06.2016).

21.Elegant $S$. In China, $\mathrm{Hu}$ is the Man to See. As the Communist Party prepares to meet, China's Hu Jintao consolidates power // Time: site [Beijing], 2007.. [Электронный pecypc]. URL: http:// content.time.com/time/magazine/article/0,9171,1668457,00.html (дата обращения: 29.11.2014).

Marchenko Gennady I. - Moscow State University MV Lomonosov (Moscow, Russian Federation). DOI: $10.17223 / 1998863 \mathrm{X} / 36 / 35$

\section{SCIENTIFIC SUBSTANTIATION OF GOVERNMENT DECISIONS IN CHINA: TRAINING \& CONSULTANCY}

Keywords: expert knowledge, decision-making, the party's image, study the CCP politburo

Researchers at the Chinese political party (CCP) believe that it is from the moment of its occurrence was based on the tradition of close cooperation with science. However, only the coming to power of President Hu Jintao and Xi Jinping is not declarative, but almost literally led to the invasion of science in the Party and the administration of the country, including personnel policy and government decision-making. As a result of this policy, a new Institute of Chinese policy, similar in appearance to some training sessions, but in fact a crucial task, as the intellectual development of senior management, and promotes the transformation of the demands of society in specific solutions, and even transfer them to the specific political program. In the so-called collective training sessions, attended not only by members of the Politburo, but the ministers and the governors of the provinces, and the lecturers are the experts, scholars, researchers of Beijing University and other regions. These sessions solve diverse goals and objectives - the formation of a strategy to link the current problems with the Chinese history and the experiences of other countries, making the practice of collective decisionmaking contributes to the formation of a unified approach (consensus) among the participants of political and administrative process. Extremely interesting technology of their conduct, which covers selection of topics and research institutions; specific selection of lecturers and development of the texts, which are then handed over to each of those present; regulations; a leading role; The role of media. It is also important functions performed by the sessions - information, symbolic; ideological and propaganda; mobilization and recruitment policy; image production.Subjects discussed questions is always concrete and linked with the test problems of Chinese society. The party leadership and corruption in its ranks; environment, employment and unemployment; development of culture and the Internet; ideology and especially the central idea of "socialism with Chinese characteristics"; "law supremacy"; Marxist philosophy, social and economic sciences. And only a third of the sessions focused on international affairs, but each of them is always designated the national interests of China, its politics and society as a whole. Analyze the experience is not only unique, but also instructive to control the state, including Russia.

\section{References}

1. The 18th National Congress of the Communist Party of China: Press Centre. (2007) A crucial measure for CPC to enhance governing capability. [Online] Available from: http://english. cpcnews.cn/92275/6281233.html. (Accessed: 11th October 2014)

2. Lu, Y. (2007) The collective study sessions of the Politburo: a multipurpose tool of China's central leadership. China Policy Institute. [Online] Available from: http://www.nottingham.ac.uk/ cpi/documents/briefings/briefing-27-collective-study-sessions-of-the-politburo.pdf. (Accessed: 7th November 2014)

3. China.org. (n.d.) Sharp students, smart studies. [Online] Available from: http://www. china.org.cn/english/congress/228788.htm. (Accessed: 19th May 2013).

4. Wencong, W., Xueqing, J. \& Jing, L.(2012) Where 'top student' has a new meaning. 16 Yan 2012. [Online] Available from: http://usa.chinadaily.com.cn/china/2011-11/29/content_14177847.htm. (Accessed: 20th November 2015)

5. Saunders, P. (2007) The Chinese Politburo Hits the Books. China Brief. 6(15). [Online] Available from: http://www.jamestown.org/articles-by-author/?no_cache=1\&tx_cablanttnewsstaffrelation_ pi1\%5Bauthor\%5D=367. (Accessed: 9th May 2012)

6. Xinhua News Agency. (2002) Politburo 1st Studying Hu Jintao: to improve the governing and rejuvenating the ability to enhance learning. [Online] Available from: http://www.news.xinhuanet. com/english/2002-11/15/content_630977.htm. (Accessed: 22nd February) 
7. Jakobson, L. \& Knox, D. (2010) New Foreign Policy Actors in China. SIPRI Policy. 26. [Online] Available from: http://books.sipri.org/files/PP/SIPRIPP26.pdf. (Accessed: 24th February 2015).

8. People's Daily Online. (2011) Chinese top leaders' collective learning over past 10 years. [Online] Available from: http://english.peopledaily.com.cn/90785/7458169.html. (Accessed: 7th April 2016).

9. Caixin Online. (2011) Social Signs Point China to The Rule of Law. A Century Weekly Editorial. 13th June. [Online] Available from: http://english.caixin.com/2011-06-13/100268658.html. (Accessed: 13th July 2011).

10. China.org.cn. (2008) Hu calls on nation to continue reform, opening up. [Online] Available from: http://www.china.org.cn/government/news/2008-12/28/content_17021754.htm. (Accessed: 19th January 2015).

11. Cpcnews.cnю (n.d.) Khu Tszin'tao: osushchestvlyat' bolee aktivnuyu politiku v oblasti zanyatosti $i$ sotsial'nykh usiliy dlya dostizheniya bolee polnoy zanyatosti [Hu: implement a more proactive employment policy and social efforts to achieve a full employment]. [Online] Available from: http://cpc.people.com.cn/GB/64093/64094/17178056.html. (Accessed: 13th April 2015)

12. Cody, E. (2008) Chinese government rethinks religion. Communist party now believes faith can restore social harmony. Washington Post. January 26.

13. China.org.cn. (2009) Netizens change China's political landscape. [Online] Available from: http://www.china.org.cn/china/opinion/2009-02/28/content_17349597.htm. (Accessed: 28th FEbruary 2012)

14. Internet v Rossii i v mire. (2016) Pol'zovateli Interneta v mire [Internet users in the world]. [Online] Available from: www.bizhit.ru/index/polzovateli_interneta_v_mire/0-404. (Accessed: 22nd July 2016).

15. Bandurski, D. (2011) The bandwagon of soft power. [Online] Available from: http://cmp. hku.hk/2011/10/24/16622. (Accessed: 24th October 2015).

16. Free-paper.com. (2011) Hu Jintao, CPC Central Committee Political Bureau of the thirty-first collective study stresses the importance value and rational use of every inch of land. [Online] Available from: http://www.f-paper.com/?i815087-Hu-Jintao-CPC-Central-Committee-Political-Bureau-ofthe-thirty-first-collective-study-stresses-the-importance-value-and-rational-use-of-every-inch-of-land. (Accessed: 16st January 2014).

17. Qiang, G. (2009). Plastic-bag ban paying off. [Online] Available from: http://www.globaltimes.cn/content/461593.shtml (Accessed: 27th august 2009).

18. People's Daily Online. (2016) Top Chinese leaders' class: 30 collective studies of the 18-th CPC Politburo. Available from: http://en.people.cn/n3/2016/0204/c98649-9014098.html. (Accessed: 4th February 2016).

19. Kahn, J. (2003) Chinese Leader Cancels Communists' Seaside Retreat. The New York Times. 4th August. [Online] Available from: http://www.nytimes.com/2003/08/04/world/chinese-leadercancels-communists-seaside-retreat.html. (Accessed: 19th October 2015).

20. Vodin, R. (n.d.) Guverovskiy institut - “mozgovoy tank” [Hoover Institution - a "brain tank”]. [Online] Available from: www.sitiation.ru/j_art_377.htm. (Accessed: 18th June 2016).

21. Elegant, S. (2007) In China, Hu is the Man to See. As the Communist Party prepares to meet, China's Hu Jintao consolidates power. [Online] Available from: http://content.time.com/ time/magazine/article/0,9171,1668457,00.html. (Accessed: 29th November 2014). 